logos_i_ethos_2017_2_(46), s. 155-166

DOI: http://dx.doi.org/10.15633/lie.2366

Алексей Гапоненков

Саратовский национальный исследовательский государственный университет имени Н. Г. Чернышевского

\title{
Красота как «непостижимое» в философии Семена Франка
}

К моменту написания книги Непостижимое (1939) русский философ Семен Франк отчетливо осознал невероятную трудность, почти невозможность соединения философского умозрения и религиозной веры, того, что

Алексей Гапоненков - доктор фрилологических наук, профессор кафедры русской и зарубежной литературы Саратовского национального исследовательского государственного университета им. Н. Г. Чернышевского (Россия).

проистекает из объективно-систематического познания реальности и личного опыта ее переживания. Он продолжал создавать систему своей «философии религии», но все больше устремлялся к богословским вопросам, традиции апофатического богословия, вместе с тем, не считая себя богословом.

Источниками книги были сочинения Платона, Плотина, Дионисия Ареопагита и Августина Блаженного (особенно их метод аналогии - analogia entis), «вплоть до Баадера и Владимира Соловьева» ${ }^{1}$. Единственным учителем своей философии Франк называл Николая Кузанского, который осуществил грандиозный замысел мистического умозрения, выразившегося в формуле docta ignorantia, или «мудрого неведения», о котором говорил еще Сократ. Выделяя сферы предметного мира, собственного бытия человека и той духовной первоосновы, которая объединяет эти реальности, автор книги Непостижимое приводит слова Кузанца: Attingitur inattingibile

1 С. Л. Франк, Непостижимое. Онтологическое введение в философию религии, в: С. Л. Франк, Сочинения, Москва 1990, с. 183. 
inattingibiliter («недостижимое достигается именно через посредство его недостижения»). Суть непостижимости Божества в том, что оно доступно человеку в той мере, в какой он видит абсолютность вещей, бесконечность целого, недостижимость иного мира, наполненного божественным сиянием.

Одно из самых интимных переживаний встречи с Божеством заключено в явлении красоты. В книге Франка, в главе 8 Святыня, замечательным образом строится не очередная эстетическая теория, а собственно то, что и составляет квинтэссенцию богословия красоты - размышления о ее абсолютной ценности, сущностной непостижимости, примиряющей гармонии мироздания, просветлении духа и спасении ${ }^{2}$.

Философ останавливается на проблеме целостности эстетического объекта. Картина, скульптура, прекрасное лицо, музыка, поэзия воспринимаются как «не анализируемое целое» ${ }^{3}$, внутренне завершенное, такое, что любой умственный анализ лишь повредит очарованию красоты. Человеческая мысль раздробляет образ, пытается выразить его в понятиях. Целостность художественного произведения проявляется в интегральности, слитности, неразложимой конкретности, созерцаемой, подобно детям, как «чистый onыт реальности» ${ }^{4}$. Это особое «металогическое единство», по философской терминологии из книги $\mathrm{He}$ постижимое.

Насколько прочно мир красоты укоренен в реальности, в «земном» бытии? Этот вопрос также занимает Франка, стремящегося найти единство «внутреннего» и «внешнего», человека и мира: «То, что выражает прекрасное, есть просто сама реальность в ее отвлеченно-невыразимой конкретности - в ее сущностной

2 Проблема красоты в творчестве Франка рассматривалась такими исследователями, как В. Бычков, Е. Бочкарева, А. Дроздек. См. В. В. Бычков, Русская теургическая эстетика, Москва 2007, с. 402-408; A. Drozdek, Frank on Beauty, «Idea. Studia nad Strukturą i Rozwojem Pojęć Filozoficznych» 18 (2006), c. 109-119.

3 С. Л. Франк, Непостижимое, ор. cit., с. 424.

4 С. Л. Франк, Непостижимое, ор. cit., с. 425. 
непостижимости» ${ }^{5}$. Он отделяет конкретную живую бытийную реальность от реальности эстетической, которая выражает первую, «пленяет» в примирении с бытием.

Следуя Канту, многие приверженцы «чистого искусства» рассматривали красоту как существующую саму по себе (Zweckmässigkeit ohne Zweck - «целесообразность без цели» - нем.), как бы вне состава предметной, незавершенной и несовершенной действительности. В русской философии Владимир Соловьев не был удовлетворен тем, что «как цель сама в себе, красота ничему служить не может» ${ }^{6}$. И ведь за что-то она ценится как «чистая бесполезность»: она выражает идеальное содержание, причем реально объективное, воплощает идею и совершенное единство целого, всеединство ${ }^{7}$.

Искусство бесконечно открыто. Кант считал в Критике способности суждения, что истина и благо могут соединиться в красоте. А Владимир Соловьев пояснял, что это справедливо лишь в отношении «общей идеальной сущности» ${ }^{8}$, что нельзя сказать об эстетической форме.

Кант восхищался возвышенной красотой звездного неба. Гете сближал живую природу и искусство. Однако оба хорошо понимали, что сотворенная красота не преследует цель конечного открытия истины, а вечно и бесконечно приближает ее. Франк делает акцент на «стихии непостижимого» ${ }^{9}$, которое переживается художником в непосредственной конкретной полноте реальности. Таким образом, сущность красоты Франк видит в «таинственном сродстве» между внутренним самобытием и первоосновой «внешнего» мира. Наша «душа» находит в ней исконную «родину».

Продуктивны мысли Франка о прекрасном как об одушевленном существе, откровении «ты»: «Прекрасное (в природе и в искусстве)

5 С. Л. Франк, Непостижимое, ор. сit., с. 427.

6 В. С. Соловьев, Красота в природе, в: В. С. Соловьев, Сочинения, т. 2, Москва 1990, c. 356 .

7 В. С. Соловьев, Красота в природе, ор. cit., с. 362.

8 В. С. Соловьев, Красота в природе, ор. сіt., с. 362.

9 С. Л. Франк, Непостижимое, ор. cit., с. 427. 
“говорит” нам что-то, “дает нам знать”, подает знак о некой тайной, скрытой, живой глубине реальности; и мы в каком-то смысле “общаемся” с прекрасным - с красотой ландшафта или прекрасного лица, с картиной, статуей, собором, музыкальным произведением, - как мы общаемся с другом, с близким...» ${ }^{10}$. Интимность диалога «я ты» скрыта в потаенной глубине сознания и выражается внешне в мимическом жесте, улыбке, слове, молчании.

В начале XX века среди немецких неокантианцев была распространена теория «вчувствования», или «одушевления» (Einfühlung). Суть ее в том, что мы «переносим» собственные чувства на эстетический объект, тем самым, «одушевляем» его. Франк решительно опровергал такого рода иллюзорный взгляд и настаивал на другом понимании «таинственного сродства» между реципиентом и произведением искусства. Он вспоминал давнюю теорию «заражения», или симпатии, восходящую к метафизике Плотина и его последователей: мы воспринимаем субъективные переживания, аналогичные душевным состояниям, впечатлениям художника, то есть «не наши эмоции [...], а настроения самих вещец̆» ${ }^{11}$. Сама реальность «заражает» нас! И мы открыты к ней состраданием или сорадостью.

Удивительно то, что метафора имеет своим истоком то же самое внутреннее сродство, которое описано Франком из «объективного сходства». Он приводит ряд метафорических аналогий. Так, «чередование звуков в третьей симфонии Бетховена передает эпопею героической борьбы человеческого духа, а звуки последней части девятой симфонии - упоение безграничного ликования», «светотени Рембрандта дают нам почувствовать метафизическую духовную глубину бытия» ${ }^{12} .$. «Перенос» осуществляется и в обратном направлении, от «внешне-пространственного бытия

10 С. Л. Франк, Непостижимое, ор. cit., с. 428.

11 С. Л. Франк, О сущности искусства. Лекция, публ. А. А. Гапоненкова, Е. П. Никитиной, в: С. Л. Франк, Саратовский текст, сост. А. А. Гапоненков, Е. П. Никитина, Саратов 2006, C. 172 .

12 С. Л. Франк, Непостижимое, ор. cit., с. 430. 
к характеристике человеческих душевных или духовных состояний» ${ }^{13}$ («падение», «подъем», «расцвет» человеческой души, «поток», «течение» жизни и т.д.), что позволяет Франку подметить первоначальную способность языка передавать «переносный» психологический смысл - свидетельство реального сходства «внешнего» и «внутреннего» бытия.

От теории обратимся к непосредственному эстетическому опыту русского философа, отраженному в его высказываниях. Британский биограф Франка Филипп Буббайер писал: «Франковская философия красоты служит выражением его личной любви к красоте» ${ }^{14}$. Осенью 1923 года Франк побывал в Риме по приглашению профессора Ло Гатто из славянского отдела Института Восточной Европы, читал лекцию о русской культуре, осматривал достопримечательности. Писатель Борис Зайцев вспоминал: «Любезная г-жа Синьорелли возила нас с Франком по Аппиевой дороге (Семен Людвигович впервые видел римскую Кампанью - помню его восторг!)» ${ }^{15}$. В письме к жене, Татьяне Франк, философ признавался: «Эти два дня я с утра до вечера изучал античность - есть красота, около которой хочется умереть, перед нею вся жизнь кажется бессмысленной. Перед Венерою Киренской я чуть не заплакал» ${ }^{16}$.

Его психологическому типу личности была свойственна меланхолия, которая позволяла мыслить, страдая, чутко воспринимая царящее в мире зло. Античность была здоровым лекарством от проявлений уныния. Имея психологическую склонность к романтическому мировосприятию, Франк как философ твердо придерживался выстраданного убеждения, идущего от Гете: «Классическое настроение [...] есть свободная покорность мировой иерархии, умение

13 С. Л. Франк, Непостижимое, ор. cit., с. 430.

14 Ф. Буббайер, С. Л. Франк. Жизнь и творчество русского философа. 1877-1950, пер.

Л. Ю. Пантиной, Москва 2001, с. 198.

15 Б. К. Зайцев, Дневник писателя, Москва 2009, с. 94.

16 Цит. по: Ф. Буббайер, С. Л. Франк. Жизнь и творчество русского философа, ор. cit., с. 156. Письмо к Т. С. Франк от 28 августа 1923 г. 
наслаждаться своей духовной самобытностью на своем месте, в нормальном ее подчинении высшим духовным силам целого» ${ }^{17}$.

В одной из своих статей о Константине Леонтьеве Франк упоминал написанную в тюрьме исповедь Оскара Уайльда De Profundis. Там, в частности, шла речь о «чувстве универсальной эстетической гармонии» ${ }^{18}$. С этим чувством напрямую связана религиозная интуиция Франка и его восприятие лирики, поэтов Гете, Пушкина, Тютчева, Райнера Марии Рильке.

Особенно проникновенно тема богословия красоты звучит в цикле статей о Пушкине, где Франк обращает внимание на «нравственную красоту» его поэтического чувства: «Поэтическое восприятие красоты - красоты женщины и красоты природы - есть для него одновременно утешающее и просветляющее религиозное сознание» ${ }^{19}$. Пушкин, признавая величие природы и божественное начало в ней, сердцем стремится к иной красоте: «дева на скале прекрасней волн, небес и бури». Он «не может “смотреть на красоту без умиления": совершенная женская красота есть для него явление чего-то, стоящего “выше мира и страстей”, и в ее созерцании он “благоговеет богомольно перед святыней красоты” ${ }^{20}$. Мятежность духа, эротическая религиозность, трагизм жизни, страдания совершенным образом переходят у Пушкина в религиозную просветленность, светлую печаль.

Православно-христианская вера Федора Тютчева, по словам Франка, была органическим плодом метафизического чувства, явленного в его религиозной поэзии: «Связь между красотой увядания, страдания, бедности во внешней природе и христианским религиозным чувством ясно выражена у Тютчева: “Эти бедные селенья...” ${ }^{21}$.

17 С. Франк, Гносеология Гете (из этюдов о Гете), в: С. Франк, Живое знание. Сборник статей, Берлин 1923, с. 70.

18 С. Л. Франк, Миросозериание Константина Леонтьева, в: С. Л. Франк, Русское мировоззрение, Санкт-Петербург 1996, с. 402.

19 С. Л. Франк, Светлая печаль, в: С. Л. Франк, Русское мировоззрение, ор. cit., с. 298.

20 С. Л. Франк, Светлая печаль, ор. cit., с. 298.

21 С. Л. Франк, Космическое чувство в поэзии Тютчева, в: С. Л. Франк, Русское мировоззрение, ор. сit., с. 337. 
На пути слияния с беспредельным он шел через страсть и тьму, искушения в «блаженстве самоуничтожения», но видел дольнее и горнее: «В грустной улыбке увядающей природы, метафизически тождественной с красотой и силой человеческого страдания, уничтожается тем самым и разлад между мятежной человеческой душой и гармоническим единством природы, вопрос о котором мучил, как досадный диссонанс, космическое сознание Тютчева» ${ }^{22}$.

Гармония мироздания в красоте образов вступала в резкое противоречие с дисгармонией расколотой действительности, неудовлетворенности человеческого духа. Можно сказать, Франк подмечает и трагедию, душевный конфликт великих русских писателей (Гоголь, Достоевский, Толстой), стремившихся к полноте духа, но очень трудно переживавших в себе столкновение двух устремлений одновременно - и к художественной правде, изображению реальности, и к спасению мира. В статье Религиозное сознание Гоголя, впервые опубликованной по-немецки в католическом журнале «Hochland» в 1934 году, философ писал:

Художественное и эстетическое как таковое отвергается, потому что они легко уводят человеческий дух в чисто идеальную сферу, отделенную от реальной жизни и потому отвлекают его от великой задачи подлинного, реального просветления мира и его спасения - единственного, что нужно делать. Гоголь первым выразил типично религиозную установку русского духа на искусство. Оно всегда является или должно быть больше чем «чистое искусство», а именно - функцией или орудием стремления к святости. Он первым заметил пророческую черту подлинно русского лиризма, глубочайшая сущность которого заключается в стремлении к Богу ${ }^{23}$.

Гоголь предсказал явление Достоевского, у которого «мир спасет красота» (слова из романа Идиот, ч. 3, гл. V).

22 С. Л. Франк, Космическое чувство в поэзии Тютчева, ор. сі., с. 339.

23 С. Л. Франк, Религиозное сознание Гоголя, пер. А. Власкина, в: С. Л. Франк, Русское мировоззрение, ор. сit., с. 307. 
Заметим, что в статье о Гоголе Франк упоминает и Л. Толстого, сопоставляя их «душевный конфликт» и последнюю религиозную установку «ко вселенскому духовному совершенству», спасению: «Лев Толстой полустолетием позже <Гоголя>, из глубокой потребности исцеления души, пережил ту же самую потрясающую трагедию отказа от искусства и красоты, тот же самый поворот к ограниченному религиозному морализму» ${ }^{24}$. Этот «поворот» привел Л. Толстого к отречению от мира, аскетике, воздержанию, обеднению, «беднейшей» религиозности: «Мистическая полнота православной литургии в ее несравненной красоте, с присущей ей ощущением непосредственного присутствия Бога в таинстве и иконах, имманентность небесного в человечески-земном ему ненавистны как суетное идолопоклонство» ${ }^{25}$.

Напротив, Константин Леонтьев верил в «высшую метабизическую иенность красоть, которая заключается в свободном космическом проявлении полноты жизни...» ${ }^{26}$. Он выступал против упрощения и обеднения жизни, против всего мещанского, прозаического, убогого в человеке и обществе и видел «цветущую сложность» реальности, поэтически воспринимая ее. Не для удовольствия созерцающего, а для выражения внутреннего высокого закона жизни, как и природы.

Понимание красоты в философии Франка не обходится без опыта ее теоретического постижения Владимиром Соловьевым в статьях Красота в природе и Общий смысл искусства. Он доказывал, что красота в природе объективна и имеет онтологическое основание. Взяв эпиграфом слова Достоевского «Красота спасет мир», Владимир Соловьев высказывает мысль об улучшении действительности посредством эстетически прекрасного. Это «символ лучшей надежды, минутная радуга на темном фоне нашего

24 С. Л. Франк, Религиозное сознание Гоголя, ор. cit., с. 307.

25 С. Л. Франк, Лев Толстой как мыслитель и художник, в: С. Л. Франк, Русское мировоззрение, ор. сіt., с. 473.

26 С. Л. Франк, Константин Леонтьев, русский Ницие, пер. В. Курапиной, в: С. Л. Франк, Русское мировоззрение, ор. сіt., с. 407. 
хаотического существования» ${ }^{27}$. Больше того, красота способна укрощать тьму, «нужна для исполнения добра в материальном мире» ${ }^{28}$. Искусство же берет на себя миссию «вдохновенного пророчества» ${ }^{29}$. Но соглашается ли с этим автор Непостижимого?

Опыт мирового искусства, русской и немецкой литературы, история эстетики ставит перед Франком много трудных вопросов. Разрешает ли красота трагизм человеческого существования, находит ли человек выход из страшного «онтологического разлада»? Пессимизм философа здесь проявляется в полной мере. Франк говорит о «недостаточной онтологической обоснованности того, что открывается нам в эстетическом опыте» ${ }^{30}$. Эстетическая реальность не может объять всей глубины бытия, но она напоминает нам о «первичном единстве». «Красота относится скорее лишь к “облику” реальности, чем составляет ее подлинное существо, ее корень...» ${ }^{31}$. Художник останавливается перед тайной и загадкой: «красота как таковая не спасает его ни от разрушающих сил зла, ни от трагизма человеческой жизни. Красота как таковая нейтральна, в каком-то смысле равнодушна к добру и злу» ${ }^{32}$. Франк высказывает идею потенциальной гармонии бытия, которую выражает красота, сосуществуя с актуальной «земной» дисгармонией. Красота, по мысли философа, лишь отблеск «рая», и поэтому «как таковая не есть сама то исконное, онтологически прочное и глубинное единство, которого мы ищем» ${ }^{33}$. В религиозной философии Франка триада «истина, добро и красота» переживается в личном опыте «бытия в Боге», в Его непостижимости.

В. С. Соловьев, Красота в природе, ор. сіt., с. 352.

В. С. Соловьев, Общий смысл искусства, в: В. С. Соловьев, Сочинения, ор. сіt., т. 2, с. 392.

В. С. Соловьев, Общий смысл искусства, ор. сіt., с. 399.

С. Л. Франк, Непостижимое, ор. cit., с. 432.

С. Л. Франк, Непостижимое, ор. cit., с. 432.

С. Л. Франк, Непостижимое, ор. cit., с. 432.

С. Л. Франк, Непостижимое, ор. cit., с. 433. 


\section{Библиография}

Bubbayer F., S. L. Frank. Zhizn' i tvorchestvo russkogo filosofa, 1877-1950, per. L. Yu. Pantinoy, Moskva 2001.

Bychkov V. V., Russkaya teurgicheskaya estetika, Moskva 2007.

Drozdek A., Frank on Beauty, «Idea. Studia nad Strukturą i Rozwojem Pojęć Filozoficznych» 18 (2006), c. 109-119.

Frank S., Gnoseologiya Gete (iz etyudov o Gete), в: S. Frank, Zhivoe znanie. Sbornik statey, Berlin 1923, c. 27-70.

Frank S. L., Konstantin Leont'ev, russkiy Nitsshe, per. V. Kurapinoy, B: S. L. Frank, Russkoe mirovozzrenie, Sankt-Peterburg 1996, c. 404-422.

Frank S. L., Kosmicheskoe chuvstvo v poezii Tyutcheva, B: S. L. Frank, Russkoe mirovozzrenie, Sankt-Peterburg 1996, c. 312-340.

Frank S. L., Lev Tolstoy kak myslitel' i khudozhnik, B: S. L. Frank, Russkoe mirovozzrenie, Sankt-Peterburg 1996, c. 459-480.

Frank S. L., Mirosozertsanie Konstantina Leonteva, в: S. L. Frank, Russkoe mirovozzrenie, Sankt-Peterburg 1996, c. 399-404.

Frank S. L., Nepostizhimoe. Ontologicheskoe vvedenie v filosofiyu religii, B: S. L. Frank, Sochineniya, Moskva 1990, c. 181-559.

Frank S. L., O sushchnosti iskusstva. Lektsiya, publ. A. A. Gaponenkova, E. P. Nikitinoy, в: S. L. Frank, Saratovskiy tekst, sost. A. A. Gaponenkov, E. P. Nikitina, Saratov 2006, c. 168-178.

Frank S. L., Religioznoe soznanie Gogolya, per. A. Vlaskina, в: S. L. Frank, Russkoe mirovozzrenie, Sankt-Peterburg 1996, c. 302-311.

Frank S. L., Svetlaya pechal', в: S. L. Frank, Russkoe mirovozzrenie, Sankt-Peterburg 1996, c. 288-302. Solov'ev V. S., Krasota v prirode, в: V. S. Solov'ev, Sochineniya, t. 2, Moskva 1990, c. 351-389. Solov'ev V. S., Obshchiy smysl iskusstva, B: V. S. Solov'ev, Sochineniya, t. 2, Moskva 1990, c. 390-404. Zaytsev B. K., Dnevnik pisatelya, Moskva 2009.

\section{Красота как «непостижимое» в философии Семена Франка}

Одно из самых интимных переживаний встречи с Божеством заключено в явлении красоты. В книге С. Л. Франка «Непостижимое» (в главе 8 Святыня) замечательным образом строится не очередная эстетическая теория, а собственно то, что и составляет квинтэссенцию богословия красоты - размышления о ее 
абсолютной ценности, сущностной непостижимости, примиряющей гармонии мироздания, просветлении духа и спасении. Франк высказывает идею потенциальной гармонии бытия, которую выражает красота, сосуществуя с актуальной «земной» дисгармонией. Эстетическая реальность не может объять всей глубины бытия, но она напоминает нам о «первичном единстве».

\section{Ключевые слова}

С. Л. Франк, красота, богословие красоты, непостижимое, Божество, эстетический опыт

\section{Abstract \\ Beauty as "the Unknowable" in Semen Frank's Philosophy}

One of the most intimate feelings caused by the meeting with Divinity encompasses the phenomenon of Beauty. In the Chapter $8^{\text {th }}$ Holiness of his book entitled The Unknowable as well as in other works, Frank hasn't just developed another aesthetic theory, he's figured out the quintessence of the theology of beauty consisting of the speculations on its absolute value, essential inconceivability, reconcilable harmony of the universe, spiritual enlightenment and salvation. Frank states the idea of potential harmony of existence expressed through beauty that coexists with current "worldly" discord. Aesthetic reality is unable to grasp the depth of existence, but it reminds us of "primary unity."

\section{Keywords}

Semen Frank, beauty, the theology of beauty, the unknowable, Divinity, aesthetic experience

\section{Abstrakt}

\section{Piękno jako „niepojęte” w filozofii Siemiona Franka}

Jedno z najbardziej intymnych przeżyć spotkania z Bóstwem wyraża się w zjawisku piękna. W książce pt. Niepojęte (rozdz. 8 Świątynia) i innych pracach Siemion Frank 
buduje nie tyle kolejną teorię estetyczną, ile kwintesencję teologii piękna, czyli rozważa jego absolutną wartość, niepojętość, jednoczącą harmonię świata, oświecenie ducha i zbawienie. Frank głosi ideę potencjalnej harmonii bytu, którą wyraża piękno, współistniejąc z aktualną „ziemską” dysharmonią. Realność estetyczna nie może ogarnąć całej głębi bytu, lecz przypomina nam o jego „pierwotnej jedności”.

\section{Słowa kluczowe}

Siemion L. Frank, piękno, teologia piękna, niepojęte, Bóstwo, doświadczenie estetyczne 